\title{
Pendidikan Melalui Aktivitas Musikal dalam Ibadah Online Anak Sekolah Minggu GMIM Exodus Paniki Dua Manado
}

\author{
${ }^{1}$ Alrik Lapian, ${ }^{2}$ Meyltsan Herbert Maragani, ${ }^{3}$ Stefanny Mersiany Pandaleke \\ ${ }^{1}$ Program Studi Musik Gereja IAKN Manado, ${ }^{2}$ Program Studi Pendidikan Musik Gereja IAKN \\ Manado ${ }^{3}$ Program Studi Pendidikan Musik Gereja IAKN Manado \\ 1alriklapian@yahoo.com, ${ }^{2}$ ilzan_maragani@iakn-manado.ac.id ${ }^{3}$ stefanny@iakn- \\ manado.ac.id
}

\begin{abstract}
Abstrak
Pendidikan melalui musik, sejatinya menitikberatkan pada bagaimana musik digunakan sebagai alat pendidikan, tidak hanya dalam kegiatan belajar tentang musik tetapi juga mencakup segala aktivitas musikal yang dilakukan baik dalam bentuk kegiatan apresiasi maupun kreasi. Tujuan penelitian ini untuk mengkaji proses pendidikan melalui aktivias musikal dalam ibadah online Anak Sekolah Minggu GMIM Exodus Paniki Dua Manado. Metode yang digunakan adalah metode kualitatif dengan pendekatan pendidikan seni. Hasil penelitian menjelaskan bahwa, pendidikan melalui aktivitas musikal dalam ibadah online Anak Sekolah Minggu memiliki manfaat sebagai penguat aspek kognitif, afektif dan psikomotor yang bersifat individual, dan bukan bersifat komunal sebagai ciri umum dari proses pendidikan dalam ibadah online. Aplikasinya dalam kegiatan ibadah online Anak Sekolah Minggu GMIM Exodus Paniki Dua, berlangsung dalam setiap aktivitas musikal seperti ekspresi diri, observasi dan apresiasi yang tergambar dalam aktivitas gerak dan lagu yang dilakukan selama peribadatan berlangsung.
\end{abstract}

Kata kunci: Pendidikan Musik, Aktivitas Musikal, Anak Sekolah Minggu

\begin{abstract}
Education through music, actually focuses on how music is used as an educational tool, not only in learning activities about music but also includes all musical activities carried out both in the form of appreciation and creation activities. The purpose of this study was to examine the educational process through musical activities in online worship for GMIM Exodus Paniki Dua Manado Sunday School Children. The method used is a qualitative method with an art education approach. The results of the study explain that education through musical activities in Sunday School Children's online worship has benefits as a reinforcement of cognitive, affective and psychomotor aspects that are individual, and not communal as a general feature of the educational process in online worship. Its application in online worship activities for GMIM Exodus Paniki Dua Sunday School Children, takes place in every musical activity such as self-expression, observation and appreciation which is reflected in the movement and song activities performed during worship..
\end{abstract}

Keywords: Music Education, Musical Activity, Sunday School 


\section{Pendahuluan}

Pada dasarnya seni seharusnya menjadi dasar dari pendidikan. Demikian pernyataan yang dikemukakan oleh Plato yang dikutip oleh Read dalam bukunya. ${ }^{1}$ Pernyataan tersebut memunculkan suatu paradigma baru tentang pendidikan seni, yaitu pendidikan seni tidak semata-mata tentang seni itu sendiri (tekstual). Artinya, pendidikan seni bukan hanya mengenai bagaimana suatu seni atau suatu keterampilan berkesenian diwariskan tetapi juga bagaimana seni digunakan sebagai sarana pendidikan.

Konsep pendidikan melalui seni (education through art), termasuk didalamnya pendidikan melalui musik, menitikberatkan pada bagaimana musik digunakan sebagai alat pendidikan, tidak hanya dalam kegiatan belajar tentang musik tetapi juga mencakup segala aktivitas musikal yang dilakukan baik dalam bentuk kegiatan apresiasi maupun kreasi. Hal tersebut mengindikasikan bahwa inti dari pendidikan melalui musik ialah suatu proses internalisasi nilai-nilai dalam kegiatan berkesenian atau aktivitas musikal. Hal ini sesuai dengan pernyataan Jazuli, bahwa pendidikan seni merupakan bagian dari pendidikan nilai. ${ }^{2}$

Musik merupakan unsur penting dalam peribadatan umat Kristen, terlebih dalam ibadah anak-anak. Persentase

\footnotetext{
${ }^{1}$ Herbert Read, Education Through Art, (London: 1970) hlm. 1
}

aktivitas musikal seperti gerak dan lagu dalam ibadah anak mengambil bagian lebih dari $50 \%$ dari keseluruhan proses peribadatan. Hal ini menandakan bahwa musik memiliki peran yang sangat besar serta menjadi suatu alat atau sarana pendidikan dalam ibadah Anak Sekolah Minggu.

Pendidikan melalui musik dalam peribadatan Anak Sekolah Minggu, tidak hanya menekankan pada penanaman nilai melalui kata-kata dalam lagu (lirik) atau pujian yang dinyanyikan tetapi juga melalui aktivitas Anak Sekolah Minggu yang dilakukan secara bersama-sama, seperti bernyanyi menggunakan gerakan (gerak dan lagu), bermain games, dan lain sebagainya. Oleh sebab itu, pemberdayaan musik dalam ibadah Anak Sekolah Minggu perlu dirancang secara matang guna mengoptimalisasi peran musik sebagai sarana pendidikan.

Menghadapi pandemi Covid-19 yang sedang melanda dunia pada saat ini, beberapa kebijakan telah dibuat dalam upaya penanganan penyebaran virus Covid-19. Berbagai himbauan yang dikeluarkan oleh WHO seperti physical distancing dan himbauan untuk tetap dirumah (stay at home) memunculkan berbagai perubahan, salah satunya pembatasan mobilitas masyarakat di luar rumah yang terlihat dari munculnya gerakan bekerja, belajar dan beribadah

\footnotetext{
2 Jazuli, Paradigma Pendidikan Seni, (Semarang: 2016) hlm. 26
} 
Clef: Jurnal Musik dan Pendidikan Musik | Vol. II | No. 1 | Hal. 19 - 31 elSSN: $2746-7473$

dari rumah. Adanya kebijakan tersebut menyebabkan terjadinya suatu perubahan aktivitas, salah satunya mengubah bentuk peribadatan dari peribadatan di gedung gereja, menjadi peribadatan melalui online, termasuk di dalamnya peribadatan Anak Sekolah Minggu.

Sebagaimana telah dijelaskan sebelumnya bahwa pendidikan melalui musik dalam peribadatan Anak Sekolah Minggu, tidak hanya menekankan pada penanaman nilai melalui kata-kata dalam lagu (lirik) atau pujian yang dinyanyikan tetapi juga melalui aktivitas ASM yang dilakukan secara bersama-sama. Adanya perubahan tentang bentuk peribadatan tersebut, tentunya merubah bentuk aktivitas peribadatan secara signifikan. Aktivitas yang awalnya dilakukan secara bersama-sama dalam suatu kelompok kini dilakukan secara terpisah. Aktivitas yang sebelumnya terkoneksi secara langsung kini terkoneksi melalui media virtual. Hal ini tentunya memunculkan suatu kesenjangan terkait dengan penggunaan musik sebagai sarana pendidikan dalam ibadah Anak Sekolah Minggu.

Hal tersebut melatari ketertarikan peneliti untuk mengkaji terkait aktivitas musikal dan proses pendidikan melalui musik dalam ibadah online Anak Sekolah Minggu GMIM Exodus Paniki Dua. Tujuan penelitian ini untuk mengkaji aktivitas

\footnotetext{
${ }^{3}$ Herbert Read, Education Through Art, (London: 1970) hlm. 208

4 Pono Banoe, Metode Kelas Musik, (Jakarta:2013) hlm. 14
} musikal dalam ibadah online Anak Sekolah Minggu GMIM Exodus Paniki Dia, serta mengkaji proses pendidikan melalui aktivitas musikal tersebut.

Sebagai landasan penelitian ini, maka digunakan konsep pendidikan melalui musik dari Herbert Read. Read menyatakan bahwa tiga aktivitas dalam proses pendidikan melalui musik, antara lain: 1) aktivitas berekspresi diri sebagai kebutuhan untuk mengkomunikasikan pikiran, perasaan dan emosi; 2) aktivitas observasi sebagai keinginan individu untuk merekam, mengklarifikasi pengetahuan konseptual dan membangun hal-hal yang membantu aktivitas praktisnya; 3 ) aktivitas apresiasi sebagai respon seseorang terhadap cara berekspresi orang lain atau terhadap nilai-nilai ${ }^{3}$.

Selain itu, dilengkapi dengan konsep pendidikan musik anak oleh Banoe yang menyatakan bahwa kadar musikalitas anak-anak terbagi atas 3 (tiga) bagian, yaitu anak-anak berperasaan musikal, anak-anak cakap musikal dan anak-anak yang sangat cakap musikal ${ }^{4}$. Sementara Respati $^{5}$ menguraikan bahwa esensi pendidikan musik untuk anak dapat dirumuskan dalam aspek pendidikan, psikologis dan sosial budaya.

\footnotetext{
${ }^{5}$ Reza Respati, "Esensi Pendidikan Seni Musik untuk Anak", Jurnal Saung Guru Vol. VII No. 2, 2015, hlm. 114
} 
Clef: Jurnal Musik dan Pendidikan Musik | Vol. II | No. 1 | Hal. 19 - 31 eISSN: $2746-7473$

\section{Metode}

Metode yang digunakan dalam penelitian ini adalah metode kualitatif dengan pendekatan pendidikan seni. Rohidi $^{6}$ menjelaskan bahwa penelitian seni, sebagaimana juga penelitian kualitatif, dilakukan melalui keterlibatan dalam situasi kehidupan nyata secara mendalam. Penelitian ini dilaksanakan pada tahun 2020 , dengan lokasi penelitian di GMIM Exodus Paniki Dua. Fokus dalam penelitian ini terkait dengan rumusan masalah yang dikemukakan peneliti, yaitu aktivitas musikal dalam ibadah online, yang difokuskan pada proses pendidikan yang terjadi melalui aktivitas musikal dalam ibadah online Anak Sekolah Minggu. Pengumpulan data dilakukan melalui teknik observasi, wawancara dan studi dokumen, kemudian dianalisis menggunakan konsep pendidikan musik untuk anak, dengan mengikuti alur analisis model interaktif.

\section{Hasil dan Pembahasan}

\section{a. Ibadah Online Anak Sekolah Minggu (ASM) GMIM Exodus Paniki Dua}

Pandemi covid-19 di awal tahun 2020 menjadi suatu terobosan perubahan bagi kehidupan manusia. Belajar, bekerja bahkan beribadah dari rumah menjadi tuntutan yang bersifat wajib bagi manusia di seluruh dunia. Jika sebelumnya beribadah rutin dilaksanakan di gedung

\footnotetext{
${ }^{6}$ Tjetjep Rohendi Rohidi, Metodologi

Penelitian Seni, (Semarang: 2011), hlm. 47-48
}

Gereja, tetapi dalam masa pandemi, jemaat dipaksa untuk melaksanakan ibadah dari rumah masing-masing. Tentu hal ini membuat sejumlah gereja bahkan organisasi didalamnya ikut berpikir untuk membuat kebijakan, inovasi-inovasi guna mempertahankan makna peribadatan walaupun dalam ruang virtual.

Komisi Pelayanan Anak Sekolah Minggu GMIM Exodus Paniki Dua merupakan sebuah organisasi yang menaungi pelayanan ASM di lingkungan GMIM Exodus Paniki Dua. Sejak bulan Maret 2020, dengan petunjuk Badan Pekerja Majelis Sinode GMIM, maka komisi ASM memutuskan untuk melaksanakan ibadah ASM secara virtual. Awalnya, ibadah ASM dilaksanakan melalui pengeras suara di gereja. Namun, keadaan tersebut dinilai tidak dapat menjangkau anak-anak secara keseluruhan, dengan pertimbangan GMIM Exodus Paniki Dua memiliki 27 kolom. Karena itu, ibadah online ASM selanjutnya ditayangkan melalui TV Kabel, facebook dan youtube.

Metode pelaksanaan ibadah online dilakukan dengan 2 (dua) cara, yaitu pertama, guru-guru Sekolah Minggu melakukan perekaman sebelum hari Minggu, biasanya perekaman dilaksanakan pada hari Rabu. Rekaman dalam bentuk video yang sudah diedit kemudian ditampilkan melalui TV Kabel 
Clef: Jurnal Musik dan Pendidikan Musik | Vol. II | No. 1 | Hal. 19 - 31 elSSN: $2746-7473$

dan youtube pada hari Minggu. Kedua, pelaksanaan ibadah online dilaksanakan secara langsung dari gereja pada hari Minggu, kemudian langsung disiarkan melalui TV kabel dan facebook. Ibadah online ASM GMIM Exodus Paniki Dua langsung dipandu oleh beberapa guru Sekolah Minggu yang telah melakukan persiapan peribadatan, termasuk gerak dan lagu. Sementara untuk khotbah atau cerita Alkitab untuk anak-anak, disiapkan dari komisi Anak Sinode GMIM melalui multimedia GMIM.

\section{b. Aktivitas Musikal dalam Ibadah Online ASM GMIM Exodus Paniki Dua}

Aktivitas musikal dalam ibadah online ASM GMIM Exodus Paniki Dua akan diuraikan melalui 3 (tiga) hal sesuai landasan konseptual peneliti, yaitu melalui ekspresi diri, observasi dan kegiatan apresiasi.

a. Aktivitas musikal melalui ekspresi diri

Aktivitas musikal merupakan suatu kegiatan yang melibatkan musik sebagai ungkapan ekspresi manusia. Sebagaimana yang dikemukakan $\operatorname{Read}^{7}$, bahwa berekspresi diri merupakan salah satu aktivitas dalam proses pendidikan melalui musik, guna mengkomunikasikan pikiran dan perasaan. Selain keterampilan, perspektif umum seni juga bisa dilihat sebagai urusan permainan bentuk,

\footnotetext{
${ }^{7}$ Herbert Read, Education Through Art, (London: 1970) hlm. 208

${ }^{8}$ Bambang Sugiharto, "Seni dan Pembentukan Mental Bangsa", Seminar Nasional Pendidikan Seni, 2014, hlm. 15
}

kesenangan, keindahan, hiburan, terapi, ibadah, edukasi moral dan ekspresi diri. Sugiharto $^{8}$ menjelaskan bahwa seni adalah soal rasa yang memiliki kemampuan untuk menangkap hal-hal yang esensial dalam realitas guna menggerakkan emosi pada otak dan melahirkan tindakan. Lebih lanjut lagi, Alimuddin ${ }^{9}$ mengemukakan bahwa musik merupakan alat atau media yang dapat digunakan untuk mendidik anak. Melalui musik, anak-anak dapat mengekspresikan diri, dengan nada dan lirik tertentu sehingga dapat membuat anak menjadi rileks, berimajinasi ketika mendengarkannya. Perasaan yang diekspresikan anak ketika mendengarkan musik sesuai dengan tingkat emosi, pengetahun dan daya ingat anak.

\section{Ibadah online ASM GMIM Exodus} Paniki Dua telah dilaksanakan kurang lebih selama 9 (sembilan) bulan, sejak dinyatakan pandemi covid-19. Ibadah online ASM dilaksanakan melalui live Facebook, Youtube dan TV Kabel. Jika sebelum pandemi, guru-guru Sekolah Minggu (GSM) langsung memandu secara tatap muka nyanyian dan geraknya, maka dalam ibadah online, GSM memandu nyanyian secara virtual. Terdapat 1 (satu) orang GSM yang memandu nyanyiannya, kemudian beberapa orang GSM lainnya

\footnotetext{
${ }^{9}$ Johar Alimuddin, "Lagu Anak Sebagai Salah Satu Sarana Mendidik Anak", Jurnal IImiah Pendidikan Dasar, Vol. II No. 2, 2015, hlm. 112
} 
Clef: Jurnal Musik dan Pendidikan Musik | Vol. II | No. 1 | Hal. 19 - 31 elSSN: $2746-7473$

memandu gerak lagunya sambil tetap mematuhi protokol kesehatan.

Pernyataan dari salah seorang GSM $^{10}$ menerangkan bahwa Anak-anak Sekolah Minggu GMIM Exodus Paniki Dua mengikuti ibadah secara online, dari rumah masing-masing selama beberapa bulan ini. Selain di rumah masing-masing, ASM juga sering berkumpul dalam lingkup kolom dan mengikuti ibadah online secara bersamasama. GSM $^{11}$ dari salah satu kolom menyatakan bahwa jika anak-anak lebih senang Ketika mengikuti ibadah online secara berkelompok. Karena itu, di kolom tersebut, GSM yang berperan untuk mengatur kelompok-kelompok ibadah tersebut sambal tetap mematuhi protokol kesehatan.

Beberapa pernyataan langsung diterangkan oleh Anak-anak Sekolah Minggu GMIM Exodus Paniki Dua bahwa selama ini anak-anak mengikuti ibadah online dari rumah masing-masing atau bisa juga dari rumah teman lingkup kolom. Anak-anak tersebut mengikuti gerak dan lagu yang dipandu secara virtual oleh GSM. ASM mengikuti nyanyian dan gerakannya, dengan mengekspresikan diri masing-masing. Ada yang sangat sesuai dengan gerak dan lagu yang dipandu, tetapi ada juga yang sesuai kemauan hati bergerak mengikuti lagu yang dipandu.

\footnotetext{
${ }^{10}$ Hasil Wawancara dengan Penatua ASM Margaretha Ganda, Oktober 2020.

${ }^{11}$ Hasil Wawancara dengan Ibu TulangowMailuhu, November 2020.
}

Secara umum, aktivitas ekspresi diri tidak dapat diajarkan. Read menjelaskan bahwa peran guru adalah sebagai pembantu, pemandu, dan inspirator anak $^{12}$. Karena itu, ekspresi diri merupakan wujud dari aktivitas musikal anak-anak yang ditunjukkan anak-anak berbeda antar satu dengan yang lainnya, sesuai tingkat emosi dan daya ingat anak-anak. Bernyanyi sambil melakukan gerakan dalam mengikuti ibadah online merupakan bentuk kegiatan ekspresi anak. Aktivitas musikal melalui ekspresi diri juga dapat terjadi melalui tatap muka dan virtual, dengan seseorang atau beberapa orang yang bertindak sebagai pemandu atau fasilitator, dalam hal ini adalah Guru-guru Sekolah Minggu. Melalui aktivitas musikal yang dipandu oleh GSM, maka anak-anak dapat melihat, mendengar, mengikuti dan menirukan gerak dan lagu secara virtual sesuai ekspresi diri masing-masing.

\section{b. Aktivitas musikal melalui observasi} Observasi merupakan suatu pengamatan yang dilakukan oleh seseorang terhadap benda, kegiatan atau pun fenomena yang menjadi perhatian dari orang tersebut. Ada seseorang tertentu yang dilahirkan dengan bakat merekam dengan jelas kemudian melakukan hasil pengamatan atau rekaman tersebut dengan tindakan nyata. Namun,

\footnotetext{
${ }^{12}$ Herbert Read, Education Through Art, (London: 1970) hlm. 209
} 
Clef: Jurnal Musik dan Pendidikan Musik | Vol. II | No. 1 | Hal. 19 - 31 eISSN: $2746-7473$

kebanyakan, bakat tersebut harus terus dilatih melalui observasi yang terarah. Hal ini juga berlaku bagi pengajaran seni.

Sebuah aktivitas musikal sangat melekat dengan bagaimana seseorang merekam, mengamati dan melakukan tindakan dengan melibatkan musik didalamnya. Dalam ibadah online Anak Sekolah Minggu GMIM Exodus Paniki Dua, ibadah yang dilaksanakan didominasi dengan gerak dan lagu. Hal ini memang lazim dilaksanakan sejak dahulu dalam ibadah ASM tatap muka. Tetapi, dalam ibadah online, gerak dan lagu menjadi lebih dominan, karena guru-guru Sekolah Minggu tidak bisa berinteraksi langsung dengan anak-anak.

Hal tersebut dipertegas dengan pernyataan dari penatua $\mathrm{ASM}^{13}$ bahwa dalam ibadah online, nyanyian lebih diperbanyak mengingat anak-anak lebih senang mengikuti gerak dan lagu daripada duduk diam. Persiapan sebelum ibadah online juga dilaksanakan untuk menyeragamkan gerak dan mempersiapkan lagu-lagu secara efisien. Lagu-lagu yang dipilih adalah lagu-lagu yang biasanya dinyanyikan oleh anak-anak Sekolah Minggu sewaktu masih beribadah tatap muka. Jika dalam ibadah tatap muka secara langsung, guru-guru bisa menyelipkan cerita singkat dan memberikan teguran untuk anak-anak yang kurang memperhatikan, tetapi dalam ibadah online guru-guru Sekolah Minggu tidak bisa melakukannya. Karena itu, gerak dan lagu diperbanyak dengan harapan membuat anak-anak di rumah masingmasing betah mengikuti ibadah online.

Berdasarkan penjelasan tersebut, maka anak-anak Sekolah Minggu memang melakukan perekaman melalui pengamatan terlebih dahulu terkait gerak dan lagu yang ditampilkan oleh guru-guru Sekolah Minggu. Kegiatan observasi tersebut bukan baru berlangsung saat ibadah online, tetapi telah berlangsung sejak ibadah tatap muka sebelum pandemi. Kebanyakan lagu-lagu yang ditampilkan sudah akrab dengan anakanak Sekolah Minggu. Hal ini memudahkan anak-anak saat mengikuti gerak dan lagu dari rumah masing-masing melalui media online. Namun, aktivitas observasi melalui perekaman gerak dan lagu dari masing-masing anak tentu berbeda. Ada anak-anak yang bisa merekam dan mengikuti gerak dan lagu secara utuh, tetapi ada juga anak-anak yang kurang bisa mengikutinya secara utuh. Hal ini tentu didasarkan dari kepekaan, rasa, keaktifan bahkan psikomotorik anak-anak.

c. Aktivitas musikal melalui kegiatan apresiasi

Apresiasi merupakan suatu aktivitas sebagai respon seseorang terhadap cara

\footnotetext{
${ }^{13}$ Hasil Wawancara dengan Penatua ASM Margaretha Ganda, November 2020.
} 
Clef: Jurnal Musik dan Pendidikan Musik | Vol. II | No. 1 | Hal. 19 - 31 elSSN: $2746-7473$

berekspresi orang lain atau juga terhadap nilai-nilai. Apresiasi dapat dikembangkan dengan pengajaran seni, tetapi untuk mendapatkan reaksi dari seorang anak, maka kualitas pengalaman estetik melalui seni itu sendiri menjadi hal penting untuk diperhatikan. Jazuli ${ }^{14}$ menerangkan bahwa kemampuan berapresiasi dapat diusahakan melalui berbagai pengalaman, yang ditempuh dengan cara pembiasaan, belajar tentang seni dan berkarya atau berolah seni. Apabila seni telah diterima menjadi bagian kehidupan dari seorang anak, maka seni itu akan diterima dengan penuh kesadaran dan pengertian. Hal tersebut merupakan salah satu bentuk penghargaan.

Tahap apresiasi bermula dari sebuah pengamatan atau observasi. Hal ini tentu terkait aktivitas observasi anak-anak ketika melibatkan musik didalamnya. Kemudian berlanjut ke arah penikmatan, pemahaman, penghayatan dan penilaian. Implikasi dari sikap apresiatif seseorang adalah dapat menghargai nilai-nilai, menumbuhkembangkan sikap menghormati dan tanggung jawab pada diri sendiri maupun orang lain. Lebih lanjut lagi, Chrisnahanungkara ${ }^{15}$ menjelaskan bahwa kegiatan apresiasi dalam pendidikan seni musik di gereja dilaksanakan dalam rangka memberi nilai terhadap aktivitas musik juga karya musik yang sedang berkembang. Kegiatan

\footnotetext{
14 Jazuli, Paradigma Pendidikan Seni, (Semarang: 2016) hlm. 93
} apresiasi ini bukan sekedar mencari nilai dalam lagu-lagu yang dinyanyikan, melainkan apresiasi juga dapat menanamkan nilai menghargai kepada anak-anak.

Ibadah online ASM GMIM Exodus Paniki Dua dipersiapkan dalam 2 (dua) bentuk, yaitu dengan metode perekaman dan live. Dalam metode perekaman, ibadah online telah direkam terlebih dahulu kemudian diputar pada hari Minggu. Sedangkan untuk live, ibadah online dilaksanakan di gereja pada hari Minggu, kemudian langsung disiarkan melalui TV Kabel dan Facebook. Pada ibadah online ASM tingkat jemaat terakhir di tahun 2020, ibadah dilaksanakan secara live. Terdapat beberapa guru-guru Sekolah Minggu yang menjadi fasilitator di gereja. Karena ibadah tersebut merupakan ibadah ASM tingkat jemaat terakhir di tahun 2020, maka guruguru Sekolah Minggu berinisiatif untuk menampilkan 1 (satu) kelompok ASM menjadi pemandu gerak dan lagu, dengan tujuan supaya anak-anak bisa menyaksikan sesuatu yang baru di rumah melalui media online. Ketika gerak dan lagu ditampilkan oleh anak-anak seumuran, maka anak-anak lain di rumah mungkin bisa lebih merasa senang, berani, termotivasi dan bangga dengan kehadiran teman-teman mereka di ibadah online tersebut.

\footnotetext{
${ }^{15}$ Ariel Januar Chrisnahanungkara, "Gereja dan Pendidikan Seni Musik Bagi Anak", Jurnal Tonika, Vol. 2 No. 1, 2019, hlm. 71-72
} 
Clef: Jurnal Musik dan Pendidikan Musik | Vol. II | No. 1 | Hal. 19 - 31 elSSN: $2746-7473$

Selama pelaksanaan ibadah online ASM sejak bulan Maret, komisi ASM GMIM Exodus Paniki Dua memantau melalui grup whatsapp guru-guru Sekolah Minggu atau langsung berhubungan melalui GSM yang bersangkutan. Memang dari 27 kolom, ada beberapa kolom yang sudah tidak aktif mengikuti ibadah online ASM, dikarenakan pada kolom tertentu sudah tidak memiliki anggota ASM atau anggota-anggota ASM sebelumnya sudah beralih ke anggota remaja. Beberapa informasi yang juga peneliti peroleh dari anak-anak Sekolah Minggu yang sempat hadir di gereja sebagai pemandu gerak dan lagu antara lain (1) anak-anak Sekolah Minggu lebih senang ketika mengikuti ibadah online secara bersama-sama dengan jumlah 3-4 orang anak, dengan begitu anak-anak bisa bernyanyi bersama; (2) anak-anak Sekolah Minggu juga mengikuti ibadah online dengan orang tua atau GSM kolom sehingga orang tua juga GSM sama-sama mengikuti gerak dan lagu yang ditampilkan; (3) anak-anak Sekolah Minggu senang mengikuti ibadah online di rumah, karena merasa lebih bebas dan tidak terikat dengan pengaturan kursi dan waktu di tempat ibadah; serta (4) anakanak Sekolah Minggu merasa ketika mengikuti ibadah online sama seperti beribadah sambil bermain gerak dan lagu, layaknya anak-anak bermain game online.

Berdasarkan penjelasan tersebut, maka dapat diinterpretasi bahwa kegiatan apresiasi anak-anak Sekolah Minggu didasarkan atas pengalaman estetik saat anak-anak mengikuti ibadah online melalui aktivitas gerak dan lagu. Tahap apresiasi bermula dari aktivitas observasi, yakni anak-anak mengamati dan merekam saat menyaksikan dan mendengarkan lagulagu yang dipandu oleh guru-guru Sekolah Minggu melalui media online. Kegiatan pendengaran dan pengamatan ini merupakan reaksi anak-anak terhadap sensasi yang timbul dari aktivitas guruguru Sekolah Minggu yang diamati dan didengar.

Selanjutnya, tahap penikmatan, yakni anak-anak Sekolah Minggu meningkatkan keseriusan, kefokusan untuk merasakan dan mengikuti gerak dan lagu secara individu maupun berkelompok. Pada tahap pemahaman, anak-anak Sekolah Minggu mulai menyaring lagulagu yang dinyanyikan. Keseragaman atau keharmonisan antar gerak dan lagu merupakan salah satu bentuk apresiasi dari tahap ini. Proses pemahaman ini berlangsung dari minggu ke minggu. Jadi, dalam tahap ini, antar seorang anak dengan yang lain memiliki pemahaman masing-masing bergantung pada pengalaman estetiknya. Tahap pemahaman juga dipengaruhi oleh usia masing-masing anak. Bagi anak-anak yang sudah berusia lebih matang atau yang sudah duduk di bangku Sekolah Dasar (SD), maka kecenderungan tingkat pemahamannya lebih tinggi.

Setelah berproses pada tahap pemahaman, anak-anak akan mengalami tahap penghayatan. Pada tahap ini terjadi 
Clef: Jurnal Musik dan Pendidikan Musik | Vol. II | No. 1 | Hal. 19 - 31 eISSN: $2746-7473$

proses mau menerima atau tidak terhadap suatu kegiatan atau aktivitas. Gerak dan lagu merupakan suatu kebutuhan dalam ibadah Anak Sekolah Minggu, terlebih dalam ibadah online. Aktivitas-aktivitas yang melibatkan musik membuat ibadah online menjadi lebih hidup ketika disaksikan melalui TV Kabel, facebook dan youtube. Tahap ini melibatkan emosi masing-masing anak, sehingga menimbulkan kesan tersendiri bagi anakanak tersebut. Dengan bernyanyi, perasaan anak menjadi lebih senang, ceria dan membantu anak untuk lebih memahami lagu yang dinyanyikan. Hal ini juga sejalan dengan yang disampaikan Alimuddin bahwa melalui bernyanyi anak akan merasa tenang dan senang, kecemasan dan ketidaknyamanan akan hilang saat anak bernyanyi ${ }^{16}$. Karena itu, lagu-lagu yang dinyanyikan dalam ibadah online ASM cenderung lagu-lagu yang ceria dan sesuai dengan apa yang dialami oleh anak-anak.

Tahap terakhir adalah penilaian, yaitu anak-anak mampu untuk memberikan tanggapan terkait kegiatan yang diamati dan dilakukan. Jika pada anak-anak yang usianya sudah duduk di bangku SD, maka tanggapan bisa disampaikan secara lisan kepada guruguru Sekolah Minggu atau orang tua yang mendampingi. Lagu-lagu apa saja yang

\footnotetext{
${ }^{16}$ Johar Alimuddin, "Lagu Anak Sebagai Salah Satu Sarana Mendidik Anak", Jurnal IImiah Pendidikan Dasar, Vol. II No. 2, 2015, hlm. 112
} disenangi atau lagu-lagu yang membuat nyaman, yang bisa berpengaruh pada spiritualitas seorang anak. Sementara pada anak-anak di bawah 6 tahun, tanggapan yang diberikan biasanya berupa tindakan, yakni berdiam diri, mengikuti gerak dan lagu dengan semangat, mengikuti gerak dan lagu hanya dengan bertepuk tangan, tertawa atau memilih bermain Bersama saudara atau anak-anak lain.

Aktivitas apresiasi berlangsung secara terus-menerus. Hal-hal yang telah diperoleh sejak ibadah offline merupakan satu-kesatuan pengalaman bagi anakanak Sekolah Minggu dalam mengikuti ibadah online. Implikasi dari kegiatan apresiasi, yaitu anak-anak bisa menghargai ibadah yang dilaksanakan oleh komisi dan guru-guru Sekolah Minggu, serta anak-anak bisa menghargai diri sendiri, keluarga dan orang lain.

\section{c. Proses Pendidikan Melalui Aktivitas Musikal dalam Ibadah Online ASM \\ Pada dasarnya musik dapat} membuat anak mencapai nilai-nilai yang dapat membentuk karakter anak tersebut. Pernyataan seni seharusnya mejadi dasar pendidikan, selaras dengan pernyataan Jazuli $^{17}$, bahwa dalam dunia pendidikan, seni dalam hal ini termasuk juga musik berfungsi untuk memenuhi kebutuhan dasar pendidikan manusia (basic

${ }^{17}$ M. Jazuli, Paradigma Pendidikan Seni (Solo: 2016) hlm.3 
Clef: Jurnal Musik dan Pendidikan Musik | Vol. II | No. 1 | Hal. 19 - 31 elSSN: $2746-7473$

experience in education). Sebagaimana dikemukakan oleh Respati ${ }^{18}$ bahwa dalam aspek pendidikan, musik sejatinya memiliki manfaat sebagai penguat aspek kognitif, afektif dan psikomotor. Oleh sebab itu, dapat dikatakan pendidikan melalui seni/musik (education through art) merupakan salah satu upaya mengoptimalkan potensi anak.

Dalam ibadah ASM GMIM Exodus Paniki Dua, proses pendidikan melalui musik yang dalam hal ini sebagai penguat aspek afektif, psikomotorik dan kognitif berlangsung dalam setiap aktivitas musikal seperti ekspresi diri, observasi dan apresiasi yang tergambar dalam aktivitas gerak dan lagu yang dilakukan selama peribadatan berlangsung. Penguatan aspek afektif dalam aktivitas musikal gerak dan lagu yang dilakukan dalam ibadah online Anak Sekolah Minggu GMIM Exodus Paniki Dua terjadi melalui proses internalisasi nilai-nilai, seperti: (1) nilai religius, yang tergambar dalam lagu-lagu yang dinyanyikan pada saat ibadah online berlangsung; (2) nilai kebersamaan dan kedisiplinan, yang tergambar dalam aktivitas bernyanyi secara bersama-sama secara virtual yang dilakukan dalam ibadah online. Prier ${ }^{19}$, dalam pernyataannya menjelaskan bahwa bernyanyi dan bermusik bersama-sama mempersatukan

\footnotetext{
${ }^{18}$ Reza Respati, "Esensi Pendidikan Seni Musik Untuk Anak", Jurnal Saung Guru, Vol. VII No. 2, 2015, hIm. 114

${ }^{19}$ Karl-Edmund Prier SJ \& Paul Widyawan, Roda Musik Liturgi: Panduan untuk Para
}

anak serta mendidik anak untuk disiplin. Selain itu, Musik dengan nada dan lirik tertentu dapat membuat rileks, memotivasi juga dapat membuat anak beimajinasi ketika mendengarkannya, sehingga ketika kegiatan gerak dan lagu dilakukan dalam kegiatan peribadatan, anak-anak dapat lebih memahami maksud dari setiap lagu yang dinyanyikan.

Selain itu, dalam aktivitas musikal gerak dan lagu yang dilakukan dalam ibadah online Anak Sekolah Minggu GMIM Exodus Paniki Dua juga terdapat penguatan aspek psikomotorik pada anak. Menurut Djohan ${ }^{20}$ terdapat beberapa aktivitas yang umum dilakukan dalam pendidikan musik untuk anak-anak sebagai penguatan aspek motorik misalnya sebagai berikut: (1) Bernyanyi, untuk membantu perkembangan anak dalam artikulasi pada keterampilan bahasa, irama, dan kontrol pernapasan; (2) Bermain musik, membantu pengembangan dan koordinasi kemampuan motorik; (3) Gerak ritmis, digunakan untuk mengembangkan jangkauan fisiologis, menggabungkan mobilitas, kekuatan, keseimbangan, koordinasi, konsistensi, pola-pola pernapasan, dan relaksasi otot.

Pendapat tersebut secara tegas menyatakan bahwa terdapat proses

Petugas Musik Liturgi (Yogyakarta: 2012) hlm. 180

${ }^{20}$ Djohan, Psikologi Musik, (Yogyakarta: 2009) hlm. 249 
Clef: Jurnal Musik dan Pendidikan Musik | Vol. II | No. 1 | Hal. 19 - 31 elSSN: $2746-7473$

penguatan aspek motorik pada aktivitas musikal gerak dan lagu dalam ibadah online Anak Sekolah Minggu GMIM Exodus Paniki Dua. Melalui aktivitas bernyanyi (gerak dan lagu) anak-anak dapat berlatih artikulasi dan bahasa, serta keseimbangan dan koordinasi juga akan terlatih ketika anak bernyanyi maupun bergerak mengikuti ritme musik yang ada.

Pada dasarnya, bernyanyi dimulai dari mendengarkan. Demikian pernyataan yang dikemukakan oleh Alimuddin. ${ }^{21}$ Dalam hal ini seorang anak akan mulai bernyanyi jika ada lagu yang dia anggap menarik, dari ketertarikannya saat mendengar perlahan-lahan dia akan menghafal dan menyanyikannya. Jadi mendengarkan lagu dan bernyanyi bagi anak-anak merupakan hal yang tidak dapat dipisahkan, sebab setelah mendengarkan lagu dan lagu itu dianggap menarik secara otomatis anak akan berusaha menghafal dan menyanyikannya. Mendengarkan musik, dapat mengembangkan keterampilan kognisi, seperti memori dan konsentrasi. Musik dapat merangsang respons relaksasi, motivasi atau pikiran, imajinasi, dan memori yang kemudian diuji dan didiskusikan secara individual ataupun kelompok.

Manfaat bernyanyi diantaranya bersifat menenangkan, membuat anak merasa nyaman, alat untuk mengekspresikan perasaan, dan

${ }^{21}$ Johar Alimuddin, "Lagu Anak sebagai

Sarana Mendidik Anak", Jurnal IImiah

Pendidikan Dasar Vol. II No. 2, 2015, hlm. 112 membantu perkembangan daya ingat anak. Hal ini menunjukan adanya penguatan aspek kognisi dalam aktivitas bernyanyi. Demikian halnya aktivitas bernyanyi dalam ibadah online anak sekolah minggu GMIM Exodus Paniki Dua. Melalui aktivitas bernyanyi dalam ibadah, anak-anak dapat lebih tenang sehingga dapat dengan mudah menerima pengajaran firman, mengingat hal-hal esensial dalam ibadah seperti tata cara berdoa, serta dapat mengekspresikan perasaan.

\section{Kesimpulan}

Aktivitas musikal dalam ibadah online Anak Sekolah Minggu GMIM Exodus Paniki Dua meliputi 3 (tiga) ranah aktivitas, yakni ekspresi diri, aktivitas observasi dan kegiatan apresiasi. Aktivitas tersebut secara umum dilakukan melalui aktivitas gerak dan lagu ASM dalam ibadah online. Kemudian, proses pendidikan melalui aktivitas musikal dalam ibadah online ASM, yaitu terlaksananya penguatan aspek afektif, psikomotorik dan kognitif melalui aktivitas musikal gerak dan lagu. Aktivitas tersebut lebih bersifat individual dan tidak bersifat komunal.

Rekomendasi yang dapat disampaikan melalui penelitian ini adalah optimalisasi keberlangsungan pelaksanaan ibadah online dengan inovasi-inovasi, khususnya terkait 
Clef: Jurnal Musik dan Pendidikan Musik | Vol. II | No. 1 | Hal. 19 - 31 elSSN: $2746-7473$

pelibatan aktivitas musikal. Di samping itu, pelaksanaan evaluasi melalui guru-guru Sekolah Minggu penting untuk dilaksanakan guna menjangkau seluruh anak-anak Sekolah Minggu di lingkungan gereja.

\section{Kepustakaan}

Alimuddin, Johar. 2015. "Lagu Anak Sebagai Salah Satu Sarana Mendidik Anak". Jurnal IImiah Pendidikan Dasar, Volume II Nomor 2, 2015: 108116.

Banoe, Pono. 2013. Metode Kelas Musik. Jakarta: PT. Indeks.

Chrisnahanungkara, Ariel Januar. 2019. "Gereja dan Pendidikan Seni Musik Bagi Anak". Jurnal Tonika, Volume 2 Nomor 1, 2019: 63-74.

Djohan. 2009. Psikologi Musik. Yogyakarta: Penerbit Best Publisher.

Febriyona, Cristie., Supartini, Tri \& Pangemanan, Like. 2019. "Metode Pembelajaran dengan Media Lagu untuk Meningkatkan Minat Belajar Firman Tuhan". Jurnal Jaffray, Volume 17 Nomor 1, 2019: 123-140.

Jazuli. 2016. Paradigma Pendidikan Seni. Semarang: CV. Farishma Indonesia.

Kaelan, H. 2012. Metode Penelitian Kualitatif Interdisipliner. Yogyakarta: Paradigma.

Prier, Karl-Edmund \& Widyawan. 2011. Roda Musik Liturgi. Yogyakarta: Pusat Musik Liturgi.

Read, Herbert. 1970. Education Through Art. London: Faber and Faber.

Respati, Reza. 2015. "Esensi Pendidikan Seni Musik Untuk Anak". Jurnal Saung Guru, Volume VII Nomor 2, 2015: 109115.
Rohidi, Tjetjep Rohendi. 2011. Metodologi Penelitian Seni. Semarang: Cipta Prima Nusantara Semarang, CV.

Rumengan, Perry. 2015. "Budaya Musik dan Pendidikan: Praktik Bermusik Sebagai Sarana Pembentuk Karakter Positif Anak Didik" makalah disampaikan pada Seminar Nasional Seni Pertunjukan dan Pendidikan Seni. Auditorium Universitas Negeri Semarang.

Sugiharto, Bambang. 2014. "Seni dan Pembentukan Mental Bangsa" makalah disampaikan pada Seminar Nasional Pendidikan Seni. Gedung Dekanat FBS UNNES. 